\title{
Article
}

\section{Antipsoriatic potential of Annona squamosa seed oil: An in-vitro and in- vivo evaluation}

Bhoir, Sandeepa S., Vishwapathi, Vinod and Singh, Kamalinder Available at http://clok.uclan.ac.uk/23614/

Bhoir, Sandeepa S., Vishwapathi, Vinod and Singh, Kamalinder ORCID: 00000001-7325-0711 (2019) Antipsoriatic potential of Annona squamosa seed oil: An in-vitro and in-vivo evaluation. Phytomedicine, 54 . pp. 265-277. ISSN $0944-7113$

It is advisable to refer to the publisher's version if you intend to cite from the work. http://dx.doi.org/10.1016/j.phymed.2018.07.003

For more information about UCLan's research in this area go to http://www.uclan.ac.uk/researchgroups/ and search for < name of research Group>.

For information about Research generally at UCLan please go to http://www.uclan.ac.uk/research/

All outputs in CLoK are protected by Intellectual Property Rights law, including Copyright law. Copyright, IPR and Moral Rights for the works on this site are retained by the individual authors and/or other copyright owners. Terms and conditions for use of this material are defined in the policies page.

\section{CLoK}

Central Lancashire online Knowledge www.clok.uclan.ac.uk

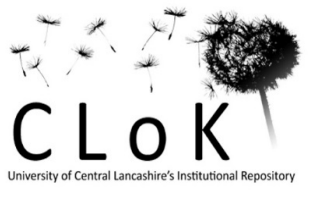




\section{1 / 37 pages}

\section{Accepted Manuscript}

Antipsoriatic potential of Annona squamosa seed

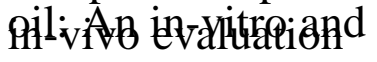

Sandeepa S. Bhoir, Vinod Vishwapathi , Kamalinder K. Singh

PII: S0944-7113(18)30255-1

DOI:

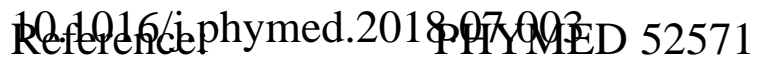

To appear in: Phytomedicine

Received date: $\quad 30$ August 2017

Revised date: $\quad 9$ June 2018

Accepted date: $\quad 13$ July 2018

Please cite this article as: Sandeepa S. Bhoir,

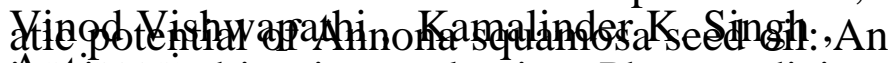

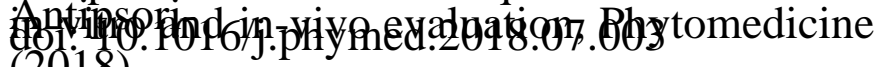
(2018),

This is a PDF file of an unedited manuscript 